\title{
A Gap Analysis of the Essential Competencies Expected and Perceived from Hospitality Graduates in the Industry: The Case of Egypt
}

\author{
Maher Fouad Hossny \\ Associate professor \\ Faculty of Tourism and Hotel Management, \\ Hotel Management Department - Beni-Suef University
}

\begin{abstract}
The purpose of this study is to examine, identify the essential competencies expected and perceived from hospitality graduates in the industry. A gap means analysis technique used to analyze hospitality managers' expectations and perceptions about Employment of Graduates in the hospitality industry. Industry management conceded that hospitality education modules need to reflect recent and future industry challenges and improvements to guarantee graduates are outfitted with suitable and industry-relevant competencies. Required data are collected with a self-administered questionnaire adapted from competency model of Chung-Herrera, Enz, and Lankau (2003). The questionnaire was distributed randomly among 280 managers of chain hotels in Egypt after permission from the directors of Human Recourses. Gathered data were examined using descriptive statistics and factor analysis method. The results of this study reveal that hospitality managers' expectation is less than their perception from Employment of fresh Graduates in the hospitality industry. Furthermore, factor analysis generates five groups of competencies required by hospitality industry namely; (Transferable Competencies, Professional Competencies, Generic Competencies, Analytical skills, and Conceptual skill). The results are very important for both of hospitality education and industry as it can help to determine and prioritize the needed competencies in the field of hospitality industry. It is therefore urgent that hospitality, educational institutions need to meet the requirements of the industry in their demand for competencies needed from the graduated.
\end{abstract}

Keywords Competencies, hospitality education, hotel industry, hotel skills, employment.

\section{Introduction}

Hospitality industry has raised concerns in regards to the shortage of appropriately qualified employees. The industry emphasized that there is an 


\section{A Gap Analysis of the Essential Competencies Expected and Perceived from Hospitality Graduates in the Industry: The Case of Egypt}

extreme deficiency of skilled employees who graduated from hospitality education, especially in the hotel management department, and that education of these potential employees needs to be more lined up with industry requirements (Raybould and Wilkins, 2005). Although, hospitality education plays a main part of both hospitality education and industry, with accentuation on building up student's competencies, rather than operational, and an aptitude (Roberts and Whitelaw, 1999). There is a gap between hospitality higher education and industry. Hospitality education needs to study the needs of what hospitality industry really needs from current hospitality graduates, which help them to develop appropriate curriculum matching with the needs of the industry. In the hospitality industry, experts expect that students will be trained for not just aptitudes and abilities at the advanced level, but to also have lots of competencies such as, critical thinking skills, enthusiastic knowledge as a result of a multi year degree (Ogbeide, 2006).

The purpose of this study was to highlight the requirements and expectations of middle management in the hospitality industry in Egypt, because a limited empirical research has been done on this topic. The specific objectives of the study were to examine (a) is there is a gap between expectation and perception competencies about the employment of graduates in the hospitality industry; and (b) what are the requirements of skills and competencies needed by the industry for future career goals. It is expected that findings would provide insights into how the hospitality industry views employment of graduates in the hospitality industry as well as how well higher institution for hospitality education has prepared students for their career challenges.

\section{Literature review}

There is a gap amongst experts and academics in every single instructive field and enterprises (Jenkins, 1999; Stanton, 2006; Anderson, 2007; Brownlie et al., 2008; Belli, 2010; Lilien, 2011). The part of educational establishments has been constantly reported that, as students getting ready for work, industry is giving them a simple direction to business and industry tasks (Waryszak, 1999; Ogbeide, 2006). The fundamental goal of hospitality education is to furnish the industry with high caliber graduates outfitted with pertinent management capabilities (Hansson, 2001; Christou, 2002). Generic and transferable skills, including initiative, communication, human resource management, and critical thinking are fundamental to profession achievement (Tas et al., 1996; Kay and Russette, 2000). Hospitality industry requirements are looking for graduates with transferable abilities, including solid composed and level of communication skills, interpersonal aptitudes, cooperation, and critical thinking abilities (DEETYA, 1998). Hospitality 


\section{Hossny, M}

management foresee that graduates have transferable generic skills in specific area such as, strategic management, communication, decision-making and basic leadership (Buergermeister, 1983; Goodman and Sprague, 1991; Cichy et al., 1992; Williams and DeMicco 1998). Professional degree or certificate programs, incorporating those in hospitality management, are proposed to fulfill the industry's developing interest for high skilled staffs. Accordingly, there exists a need to guarantee that the academic curriculum meets instructive expectations, as well as those of industry and undergraduates, with respect to the ranges of abilities required in the work environment (Raybould and Wilkins, 2005). Hospitality Education cycle plays one of the essential parts in professions of the future hospitality employees. It is extremely pivotal to recognize the contrasts between the education and training, in this manner, to have an alternate perspective on the idea of hospitality management.

Baum (1995) noticed that, colleges give the education process of the creation, food service methods, and management, while on the job-training training is given by the industry. In addition, education has been characterized as a field of multidisciplinary contemplate, which brings the points of view of numerous controls, particularly those found in the sociologies, to sustain on specific areas of use and practice in the hospitality industry (Riegel and Dallas, 2006). As indicated by Johanson et al. (2010) there are some essential skills required by the hospitality industry, for example, Communication abilities; featuring of relational abilities and language skills whether oral and written. The capability to talk confidently to clients, supervisors, and colleagues is an expertise required and utilized consistently. Alongside that, having the capability to impart thoughts to lead, motivate, educate, train, and facilitate frequently includes communicating skill. Communication skills must keep on being critical for positions in hospitality tasks.

Zegward and Hodges (2003) looked at competency as an individual trademark, and Hodges and Burchell (2003) incorporated the dependence on individual capability as opposed to technical ability. According to Zeithaml et al. (2006), in hospitality industry managers are searching for a level of service competence such as, knowledge, skills, and a tendency for service job such as, attitude and interest. Hospitality Managers frequently comment on the absence of readiness of students entering the hospitality working environment (Kember and Leung, 2005; Barrie, 2006) and that they are searching for work- ready include people with an extensive variety of mixed abilities (Yorke and Harvey, 2005). 


\section{A Gap Analysis of the Essential Competencies Expected and Perceived from Hospitality Graduates in the Industry: The Case of Egypt}

\section{Hospitality industry's perceptions relating to hospitality graduates}

Hospitality industry is considered a labour intensive; therefore, human recourses play a significant role in the industry whenever they are looking to hire employees (Grobler and Diedericks, 2009). Consequently, significant hospitality education curriculums are basic for a definitive accomplishment of this industry (Kay and Russette, 2000). The nature of the HR relies upon having the appropriate level of education, industry training, talented, and committed to industry tasks. In any case, it was noticed that over $30 \%$ of the aggregate management workforces in hospitality industry do not possess a basic capability in the hospitality industry. The hospitality industry hires graduates at entry-level or middle level positions depend on the skills they have. Hospitality managers' mentioned that graduates are not willing to begin at the base, since they trust that their capabilities should give them quick access to middle management. On the other hand, those in the hospitality industry are revealed that newcomers need to learn the cultural awareness and the actions of the business through intensive on the job-training (Moyle, 2008).

\section{Hospitality industry expectations}

Hospitality education looks to furnish undergraduates with the required aptitudes for good work opportunity and for better future occupation. From the undergraduates perspective, their choice and satisfaction with their hospitality programs and establishments, future profession prospects and simple direction to the business are ranked the higher scores in the undergraduate determination (Alhelalat et al., 2009; Gray et al., 2003). In addition, establishment's reputation, academic quality, program accreditation, and industry acknowledgment were a response to a central issue identified with what undergraduates require from their academic programs and instructors (Crisp, 2010; Spake et al., 2010; Gray et al., 2003). Hospitality Industry censured the institutions for tourism and hospitality education for unplanned individuals properly, and giving them the required training by the industry (Airey, 1988). Gill et al., (2000) added that the skills required by hospitality industry are gathered into three classifications: industry-particular or vocational skills (mostly specialized aptitudes, for example, food service and arrangement, stock management, cost control); generic skills (e.g. managerial skills, communication, problem-solving, selling skills) and competence getting from attitude to the workplace (e.g. enthusiasm, responsibility, the will to learn). 


\section{Key requirements for hospitality employees}

It is essential to distinguish between the key skills, competencies, and characteristics of hospitality staffs to decide the basic factors that help in the accomplishment of a hospitality graduate. Many studies have recognized interpersonal skills development as a main key of significance for graduates in the work environment (Nelson and Dopson, 1999; Raybould and Wilkins, 2006; Spowart, 2011). Hospitality interested for undergraduates have transferable competencies, communication, activity, inventiveness, and initiative, which empowers them to be a piece of an adaptable and versatile workforce (Bennett, 2002; Bennett et al., 1999). Hospitality Managers additionally required personal characteristics, for example, the ability to adapt to pressure, react to a change and intercultural relational skills. It is conceivable that education providers are not sufficiently responsive to the changing idea of work, the working environment and the prerequisites of managers (Gow and McDonald, 2000). Hospitality industry requires various skills of hospitality specialists, and these skills include an extensive variety of individual capacities and characteristics such as,

- Attitudinal (Lafer, 2004) - timeliness, loyalty and discipline

- Technical (Baum, 2002, 2006) - numeracy, education, frameworks learning

- Generic or soft skills (Baum, 2006; Raybould and Wilkins, 2005, 2006) e.g. communication, critical thinking

- Emotional (Hochschild, 1983) - the capacity to oversee feelings in the work environment

- Esthetic (Nickson et al., 2005; Warhurst and Nickson, 2007) - "to be looks great" and "sounding elegant"

- Cultural (Arora and Rohmetra, 2010; Baum et al., 2007; Dawson et al., 2011; Mkono, 2010) - a familiarity with social assorted variety

- Experiential (Baum, 2006) - the capacity to develop through involvement

- Linguistic (Blue and Harun, 2003), and

- Transferable (Bennett, 2002).

Kay and Russette (2000) recognized the interpersonal skill of a person as a center competency in the hospitality industry. Fallows and Steven (2000) likewise reasoned that individual achievement and performance are upgraded through abnormal amounts of interpersonal skills. This point of view is upheld in later investigations; for instance, done by Hind et al. (2007), Huang and Lin (2011) and Lolli (2013). Interpersonal skills have been valued among the most essential competencies for entrants graduated to the hospitality 


\section{A Gap Analysis of the Essential Competencies Expected and Perceived from Hospitality Graduates in the Industry: The Case of Egypt}

industry (Kay and Russette, 2000; Chung-Herrera et al., 2003; Tesone and Ricci, 2005).

\section{Research methods}

\section{Sample}

A Random sample of 280 operational hospitality middle managers was chosen randomly by using cluster sampling due to the large population, which spread, over a large geographical area. The target groups for this research were the hotels of international chains in Egypt, such as Hilton, Marriott, Four Seasons, Sheraton, Kempinsky and Radisson Blu.

\section{Research instrument}

The research instrument used in this study was a semi-structured survey based on the research questions and literature review. The survey instrument builds based on the academic and practical collection. The academic competency was based on the model: leadership competency model of Chung-Herrera, Enz, and Lankau (2003) - for employees holding nonmanagerial positions. However, the practical competency was based competency of standard training procedures for five-star hotel chain. Survey developed to ascertain hospitality managers' expectations and perceptions about the fresh employment of Graduates in the hospitality industry who had studied at the department of hotel management in different faculties of tourism and hotel management. The instrument consisted of twenty skills to rate the level of essential competencies and qualifications required by the industry. All questions used in the questionnaire had responses, which were rated on the 5-point Likert scale. In order to make answers more clear and precise, both of the competency models were presented in a scale, where managers had to rank competencies from Strongly Disagree to Strongly Agree on a Likert scale of 1 to 5, where: $1=$ Strongly Disagree $2=$ Disagree $3=$ neither disagree nor agree $4=$ Agree $5=$ Strongly Agree A modified questionnaire was used in a pilot test involving 20 hospitality managers and Hospitality academics to identify problems regarding comprehensibility of the questions as recommended by Dillman (2007). After analysis of the pilot test data, a few minor modifications were made to the format of the questionnaire before it was delivered to all participants

\section{Data collection}

The survey was conducted at five-star hotel chain, Egypt. The survey was delivered personally to directors of Human Recourses who were a contact members at each of the participating hotels. Director of Human Recourses was responsible for ensuring that the survey was administered to managers. 280 questionnaires were distributed, and $214(76 \%)$ were completed and 
considered to be valid for research purposes. Survey collected personally from each director of Human Recourses.

\section{Data analysis}

The SPSS version 24.0 was used for all analyses. Response percentages in each category were calculated and presented in tabular form. Descriptive statistics and content analysis were used to analyze the data and verify the gaps that may exist between hospitality expectations and perceptions about Employment of Graduates. Factor analysis was used to group the different competencies needed by hospitality industry

\section{Internal consistency}

To test the measurement consistency of the constraint dimensions, reliability analyses were conducted. The Cronbach's alpha coefficient scores indicated that the items used to measure these constructs were marginally reliable, as alpha scores for perception were .72 and .68 for expectation. Nunnally (1994) greater than or close to the standard of 0.70 recommended the reliability alphas, which are designed to check the internal consistency of items within each variable.

\section{Results and Discussion}

A careful analysis of Table 1 shows that 17 out of 20 competencies mean score differences are statistically significant; $\mathrm{p}<.01, \mathrm{p}<.02$ level, and $\mathrm{t}-$ values are greater than $+/-2.00$ levels (Nunnally \& Bernstein, 1994; Hair et al., 1998). Moreover, a Mean score for manager's expectation and perception are above the midpoint 3.00, indicating respondents agreed, if not strongly agreed, with the items listed under these competencies related variables. 


\section{A Gap Analysis of the Essential Competencies Expected and Perceived from Hospitality Graduates in the Industry: The Case of Egypt}

\section{Table 1: Items related to hospitality managers' expectations and perceptions about Employment of Graduates in the hospitality industry}

\begin{tabular}{|c|c|c|c|c|c|}
\hline Item & Perceptions & Expectations & Gap & $\mathbf{t}$ & $\begin{array}{c}\text { Sig. } \\
\text { (2-tailed) }\end{array}$ \\
\hline $\begin{array}{l}\text { 1. Work ethics } \\
\text { Graduated, seek to protect and build the company's } \\
\text { reputation and the morale of its colleagues by } \\
\text { engaging in conduct that builds respect and take } \\
\text { whatever actions are necessary to correct or prevent } \\
\text { inappropriate conduct of others }\end{array}$ & 3.799 & 4.320 & -.520 & $\begin{array}{c}- \\
5.09\end{array}$ & .000 \\
\hline $\begin{array}{l}\text { F. Flexibility } \\
\text { Graduated, prepared to keep different hours than the } \\
\text { rest of the workforce. He is also flexible in the way } \\
\text { he works.. }\end{array}$ & 3.697 & 4.307 & -.609 & $\frac{-}{6.13}$ & .000 \\
\hline $\begin{array}{l}\text { 3. Language Skills } \\
\text { Graduated required, to have language skills because } \\
\text { they allow him to be better able to communicate with } \\
\text { his clients. His Language skills can also help to build } \\
\text { better relationships with customer and can prove to } \\
\text { be invaluable in the long run. }\end{array}$ & 3.669 & 4.307 & -.637 & 5.92 & .000 \\
\hline $\begin{array}{l}\text { 4. Administrative } \\
\text { Graduated have the enough skills to deal with } \\
\text { personnel and financial management of the business }\end{array}$ & 3.846 & 4.307 & -.460 & $\begin{array}{c}- \\
4.49\end{array}$ & .000 \\
\hline $\begin{array}{l}\text { 5. Enthusiasm } \\
\text { Selected graduated are enthusiastic about their jobs } \\
\text { and strive to do the best work possible. They want to } \\
\text { give their customers the best experience available }\end{array}$ & 3.814 & 4.037 & -.223 & $2 . \overline{25}$ & .025 \\
\hline $\begin{array}{l}\text { 6. Pro-active } \\
\text { graduated must be very thorough in their work and } \\
\text { realize that any oversight could result in customer } \\
\text { dissatisfaction }\end{array}$ & 3.832 & 4.223 & -.390 & $\begin{array}{c}- \\
3.40\end{array}$ & .001 \\
\hline $\begin{array}{l}\text { 7. Communication Skills } \\
\text { Graduated have an excellent communication skill. } \\
\text { They can communicate effectively both orally and in } \\
\text { writing }\end{array}$ & 3.186 & 4.158 & -.972 & $\begin{array}{c}- \\
7.67\end{array}$ & .000 \\
\hline $\begin{array}{l}\text { 8. Teamwork } \\
\text { Preferred graduated have the ability to work well } \\
\text { with others and can be a productive member of a } \\
\text { team. They value the contributions of everyone. }\end{array}$ & 3.311 & 4.153 & -.841 & 8.23 & .000 \\
\hline $\begin{array}{l}\text { 9. Strategic thinking } \\
\text { Graduated have a vision for the future of the } \\
\text { department/property. }\end{array}$ & 3.418 & 4.134 & -.716 & 6.39 & .000 \\
\hline $\begin{array}{l}\text { 10. Emotional } \\
\text { Graduated have the ability to manage emotions in the } \\
\text { workplace }\end{array}$ & 4.148 & 4.255 & -.106 & $\overline{1.51}$ & .132 \\
\hline $\begin{array}{l}\text { 11. Cultural Awareness } \\
\text { Graduated required to work with people from } \\
\text { different cultural backgrounds. His ability to be } \\
\text { culturally aware and get past his own cultural norms } \\
\text { is crucial to building a successful career. He is also } \\
\text { required to break free from cultural barriers and help } \\
\text { his customers feel more comfortable }\end{array}$ & 3.083 & 4.069 & -.986 & 8.22 & .000 \\
\hline
\end{tabular}




\section{Hossny, M}

\begin{tabular}{|c|c|c|c|c|c|}
\hline \multicolumn{6}{|c|}{ Continued } \\
\hline $\begin{array}{l}\text { 12. Interpersonal Skills } \\
\text { graduated have top notch } \\
\text { interpersonal skills, as the very nature of the business } \\
\text { is to provide spectacular customer service }\end{array}$ & 3.307 & 4.018 & -.711 & $\overline{6}-\overline{59}$ & .000 \\
\hline $\begin{array}{l}\text { 13. Leadership } \\
\text { Graduated have the ability to turn ideas into } \\
\text { productive action and make significant contributions } \\
\text { to an organization's overall success. }\end{array}$ & 3.646 & 4.009 & -.362 & $3 . \overline{01}$ & .002 \\
\hline $\begin{array}{l}\text { 14. Organized } \\
\text { graduated have to be organized and multitask without } \\
\text { difficulty }\end{array}$ & 3.204 & 3.865 & -.660 & 5.64 & .000 \\
\hline $\begin{array}{l}\text { 15. Commitment } \\
\text { Graduated to be committed to ensuring customer } \\
\text { satisfaction. You must do whatever it takes to keep } \\
\text { customers happy and create repeat business. }\end{array}$ & 3.111 & 3.711 & -.600 & 4.06 & .000 \\
\hline $\begin{array}{l}\text { 16. Computer Know-How } \\
\text { Graduated have a good computer skill and is familiar } \\
\text { with a wide range of technological applications that } \\
\text { are used within the industry. }\end{array}$ & 3.200 & 3.641 & -.441 & $\begin{array}{c}- \\
3.09\end{array}$ & .002 \\
\hline $\begin{array}{l}\text { 17. Technical } \\
\text { graduated have the sufficient knowledge and skills } \\
\text { essential to producing the product or service }\end{array}$ & 3.055 & 4.088 & -1.032 & 9.32 & .000 \\
\hline $\begin{array}{l}\text { 18. Can-do Attitude } \\
\text { Graduated able to can-do attitude that will make } \\
\text { everyone feel at ease with him. He have punctuality, } \\
\text { loyalty and discipline }\end{array}$ & 3.353 & 2.669 & .683 & 4.84 & .000 \\
\hline $\begin{array}{l}\text { 19. Multitasking } \\
\text { Graduated should be multitasks and able to achieve } \\
\text { more than one objective in the same time }\end{array}$ & 3.572 & 3.497 & .074 & .532 & .595 \\
\hline $\begin{array}{l}\text { 20. Knowledgeable of Safety/Hygiene Issues } \\
\text { Graduated are familiar with rules of safety and } \\
\text { hygiene as they apply to food serving places, hotels, } \\
\text { and other places where people spend time. }\end{array}$ & 3.446 & 3.311 & .134 & .962 & .337 \\
\hline
\end{tabular}

Based on the data presented in Table 1, the most negative gaps are found to be technical competency concerning the knowledge and skills essential to producing the product or service (-1.032). Cultural Awareness (-.98605), Communication Skills (-.972), teamwork (-.841), Strategic thinking (-.716), Interpersonal Skills (-.711), Organized (-.660), Language Skills (-.637), Flexibility (-.609), Commitment (-.600). However, the lowest gaps score calculated belongs to the Work ethics (-.520), Administrative (-.460), Computer Know-How (-.441), and Enthusiasm (-.223). The pervious negative gaps demonstrate that hospitality expectation with a certain attribute is less than its perception. These results explain that the highest important negative gap found is a technical competency. This result on contrast with a research conducted by Raybould \& Wilkins (2006) in the UK and US. Their 


\section{A Gap Analysis of the Essential Competencies Expected and Perceived from Hospitality Graduates in the Industry: The Case of Egypt}

result has found technical attributes were less important than generic interpersonal and human relations attributes. However, result consistent with a previous study by Crebert et al., (2004) who emphasized on the significance of technical skills during the study and after graduation. The professional idea of hospitality management is ideal to use work-coordinated learning as a strategy for exchanging classroom exercises, and practical lectures to the work put. Hospitality Education providing such curriculums have the basics of physical facilities that allow for teaching of technical skills such as restaurant service, culinary art, and services to clients, which students will require in the hospitality industry. Those students having a mandatory semester of work-incorporated then exchange these technical skills to the genuine workplace.

On other hand these results supported with a previous studies such as, Harkison et al., (2011) who found a gap exists between what hospitality require and what hospitality education provides. He explained that the aptitudes gap alludes to the contrasting viewpoint of managers and teachers on the necessities and abilities expected to enter the workforce. Baum (2002) and Spowart (2011) added that in the hospitality industry, many employers consider that new recruits are not work prepared and not being instructed to address the issues of the industry. Therefore, hospitality management educators are encouraged to focus on the variables with the biggest negative gap that is statistically significant because these variables are not meet the hospitality expectations.

One of the most important results is the positive variable gap of graduated attitude (.683). This indicates that the manager's perception with a graduated attitude is higher than their expectation. This result consistent with a pervious study by Harkison et al. (2011) who stated that there is a uniqueness in view between hospitality graduates and industry managerd; while students think that their knowledge and skills after graduation are sufficient to get a job in the industry managers focus on personality and initiative. Industry executives' perspectives recommend that managers esteem attitude characteristics more than skills.

A paired t-test conducted on the perception and expectation means to determine whether there is a significant difference between the means or whether this difference is due to random chance. Table 2 shows the descriptive statistics for hospitality managers' expectations and perceptions 
Table 2: Mean for hospitality managers' expectations and perceptions

\begin{tabular}{lll|l|l|l} 
& & Mean & $\mathrm{N}$ & Std. Deviation & Std. Error Mean \\
\hline Pair 1 & Perception & 70.7395 & 215 & 10.22856 & .69758 \\
\cline { 2 - 6 } & expectation & 78.0558 & 215 & 8.32161 & .56753 \\
\hline
\end{tabular}

about Employment of Graduates in the hospitality industry. The result indicates that the average mean of skills perceived by Graduates in the hospitality industry (70.73) less than the expected skills from them (78.05).

Based on the results of the paired t-test in table 3, the results showing a statistical difference between perception and expectation gaps in 17 items out of twenty and thus should be considered.

Table 3: Paired Samples Test- Perception and expectation

\begin{tabular}{|c|c|c|c|c|c|c|c|}
\hline \multirow[t]{2}{*}{ Pair 1: } & \multirow[t]{2}{*}{ Mean } & \multirow[t]{2}{*}{$\begin{array}{c}\text { Std. } \\
\text { Deviation }\end{array}$} & \multicolumn{2}{|c|}{$\begin{array}{c}95 \% \\
\text { Confidence } \\
\text { Interval of the } \\
\text { Difference }\end{array}$} & \multirow[t]{2}{*}{$\mathrm{t}$} & \multirow[t]{2}{*}{$\mathrm{df}$} & \multirow[t]{2}{*}{$\begin{array}{l}\text { Sig. (2- } \\
\text { tailed) }\end{array}$} \\
\hline & & & Lower & Upper & & & \\
\hline $\begin{array}{l}\text { Perception- } \\
\text { expectation }\end{array}$ & -7.316 & 13.371 & $\begin{array}{c}- \\
9.113\end{array}$ & 5. & -8.023 & 214 & .000 \\
\hline
\end{tabular}

The dependent samples t-test showed an average reduction in perception scores with 7.316 than the expectation scores with a standard deviation of 13.371 in the sample of 214 Employment of Graduates in the hospitality industry. This results in a t-value of $t=-8.023$ with 214 degrees of freedom. The dependent sample t-test was used to account for managers differences in the perception-expectation of the Graduates. The observed decrease is highly significant $(\mathrm{p}=0.001)$. Therefore, the result reveals that there is a gap difference in means of expectation and perception competencies about the employment of graduates in the hospitality industry. In addition, with $99.9 \%$ confidence the observed reduction in perception score can also be found in the general population. With a $5 \%$ error rate, that the difference in perception and expectation of the graduates' scores will be between -9.11384 and 5.51872 . 


\section{A Gap Analysis of the Essential Competencies Expected and Perceived from Hospitality Graduates in the Industry: The Case of Egypt}

This finding is consistent with the literature that criticism the higher education programs were in fact getting to be distant from the immediate needs of the industry (Beth et al. 2003). Sharp difference has been noticed in the hospitality literature between hospitality educators and industry experts with respect to the degree to which hospitality educators are responsible for competencies, internship, and competency development (Harper et al., 2005; Williams 2005). In accordance with the findings of Jebril (2015) there is a gap between hospitality education outcomes and industry needs in relation to what competencies should graduates acquire and the degree to which they match what hospitality industry requires. The academic outcomes and business essentials of the hospitality industry are not identical in reality as the current field study concludes.

\section{Factor analysis}

To examine the variables of the competencies required by the hospitality industry for graduates hotel employees, a principal component factor analysis with varimax rotation was implemented. As the KMO (Kaiser-Mayer-Olkin) measure of sampling adequacy indicated .721, the factor analysis was believed to be a useful validation of the factor model. The mean skills gaps for all twenty skills required by hospitality industry items are determined. The higher the negative perceived- expected of the skills gap, the lesser is the chance of hospitality managers' expectations meeting the perceptions' level. Hence, seventeen items having higher mean service quality gaps were identified and analyzed through Factor Analysis. The 17 items yielded five factors with eigenvalues greater than 1.0 (Table 4). These factors explained $54.58 \%$ of the variance and were labeled: (1) Transferable competency, (2) Professional Competencies, (3) generic competency, (4) Analytical skills, and (5) Conceptual skill. Table 4 shows the analysis of the 17 items was conducted, followed by varimax rotation to examine their dimensionality. The criteria for the number of factors extracted was determined on the basis of percentage of variance extracted by the factors reach at least $40 \%$ of the cumulative variance. Items with eigenvalue equal to or greater than 1 were chosen for interpretation. Factor analysis identified five underlying dimensions 
Table 4: Rotated Component Matrix for hospitality managers' expectations and perceptions about Employment of Graduates

\begin{tabular}{|c|c|c|c|c|c|}
\hline \multirow[t]{2}{*}{ in the } & \multicolumn{3}{|c|}{ hospitality industry } & \multirow[b]{2}{*}{4} & \multirow[b]{2}{*}{5} \\
\hline & 1 & 2 & 3 & & \\
\hline Q3 & .861 & & & & \\
\hline Q1 & .846 & & & & \\
\hline Q2 & .804 & & & & \\
\hline Q7 & .514 & & & & \\
\hline Q6 & .407 & & & & \\
\hline Q17 & & .663 & & & \\
\hline Q8 & & .634 & & & \\
\hline Q15 & & .610 & & & \\
\hline Q12 & & & .810 & & \\
\hline Q11 & & & .785 & & \\
\hline Q13 & & & .593 & & \\
\hline Q16 & & & & .817 & \\
\hline Q4 & & & & .622 & \\
\hline Q14 & & & & .557 & \\
\hline Q9 & & & & & .662 \\
\hline Q5 & & & & & .579 \\
\hline Q18 & & & & & .578 \\
\hline Eigen Values & 4.391 & 2.511 & 1.511 & 1.347 & 1.158 \\
\hline Variance Explained (\%) & 21.95 & 12.55 & 7.55 & 6.73 & 5.78 \\
\hline $\begin{array}{l}\text { Cum Variance Explainec } \\
(\%)\end{array}$ & 21.95 & 34.50 & 42.05 & 48.79 & 54.58 \\
\hline
\end{tabular}

From the previous matrix, the highest factor loading for each item is specified. The results indicate that items 3, 1,2, 7, and 6 combine to define the first factor; items 17,8 and 15 combine to define the second factor; the third factor contained the items 12,11 , and 13 ; items 16,4 and 14 combine to define the fourth factor and item 9,5 and 18 are identified in the fifth factor. The underlying dimension for each factor is identified and shown in Table 5 
Table 5: Factors and their underlying dimensions

\begin{tabular}{|c|c|c|c|}
\hline \multirow{5}{*}{$\begin{array}{c}\text { Factor } \\
1\end{array}$} & Q3 & Language Skills & \multirow{5}{*}{$\begin{array}{l}\text { Transferable } \\
\text { Competencies }\end{array}$} \\
\hline & Q1 & Work ethics & \\
\hline & Q2 & Flexibility & \\
\hline & Q7 & Communication Skills & \\
\hline & Q6 & Pro-active & \\
\hline \multirow{3}{*}{$\begin{array}{l}\text { Factor } \\
2\end{array}$} & Q17 & Technical, & \multirow{3}{*}{$\begin{array}{c}\text { Professional } \\
\text { Competencies }\end{array}$} \\
\hline & Q8 & Teamwork & \\
\hline & Q15 & Commitment & \\
\hline \multirow{3}{*}{$\begin{array}{c}\text { Factor } \\
3\end{array}$} & Q12 & Interpersonal Skills & \multirow{3}{*}{ Generic Competencies } \\
\hline & Q11 & Cultural Awareness & \\
\hline & Q13 & Leadership & \\
\hline \multirow{3}{*}{$\begin{array}{c}\text { Factor } \\
4\end{array}$} & Q16 & Computer Know-How & \multirow{3}{*}{ Analytical skills } \\
\hline & Q4 & Administrative & \\
\hline & Q14 & Organized & \\
\hline \multirow{3}{*}{$\begin{array}{c}\text { Factor } \\
5\end{array}$} & Q9 & Strategic thinking & \multirow{3}{*}{ Conceptual skill } \\
\hline & Q5 & Enthusiasm & \\
\hline & Q18 & Can-do Attitude & \\
\hline
\end{tabular}

These groups of competencies are very important for both of hospitality education and industry as they can help to determine and prioritize the needed competencies. The importance of this groping is supported by a study by Millar et al., (2008) who explained that when industry managers and educators specify the actual aptitudes and skills required by hospitality industry, they can categorize them into different groups, accordingly empower management to quickly assess where an employee performing well or lags in a particular group. As educators and professionals communicate with each other, it will become easier to identify the competencies that can be incorporated into the groups and then into classroom curriculum to 


\section{Practical implications}

The current study helps to focus on competencies under hospitality expectation, which need immediate attention to enhance the hospitality education. Furthermore, to raise the standards of hospitality education, procedure, and outcomes in relation to the particular competencies required by the industry; specially technical competency concerning the knowledge and skills essential to producing the product or service, Cultural Awareness, Communication Skills, teamwork, Strategic thinking, Interpersonal Skills, Organized, Language Skills, and commitment.

\section{Conclusions}

This study mainly is focused on identifying the skills and competencies required for the hospitality industry and middle management expectation and precipitation about the employment of graduates in the hospitality industry. The findings have implications for management, instructors, fresh employees, and students. Hospitality management is urged to structure the induction and training of new graduates exploit their solid mentor competencies. The implication of the above findings is that hospitality management institutions should take care of those competencies perceived as essential for the field by rehearsing experts, and provide curriculum to develop them. The results of the study achieved the research objectives, as the results indicate that a gap found between hospitality managers' expectations and perceptions about the employment of graduates in the hospitality industry. The expectations of the managers are determined by the essential competencies and qualifications required by the industry, which graduated, acquired from the education of hospitality management. The results of the study indicate that hospitality graduates' competencies are not met to the industry requirement.

Middle management requires that students should have more Transferable Competencies, Professional Competencies, Generic Competencies, Analytical skills, and Conceptual skill in order to match the standards of the industry for hospitality graduates' Competencies. However, the industry also has certain perceptions to measure skills and ability to manage the operation, time, situations, and guests. It is important to determine the gap that may exist between hospitality expectations and perceptions about employment of graduates, so that graduates are better developed and trained for a career in a challenging industry. The results indicated that there are some gaps between hospitality expectations and perceptions about Employment of Graduates in 


\section{A Gap Analysis of the Essential Competencies Expected and Perceived from Hospitality Graduates in the Industry: The Case of Egypt}

the hospitality industry. In fact, the gap analysis approach conducted to evaluate the hospitality education outcomes rather than the graduated. The results are in contrast to a study done by Cho et al., (2007) on the gap between hospitality education and industry which explain the significant gaps and interesting differences on perceptions about hospitality education exist between what student acquired from skills during his study and hospitality needs. This result can help of both the educators and hospitality professionals to prioritize and emphasize the items with highest significant negative gaps and de-emphasized the items with positive or non-significant gaps. In addition, according to Milman \& Ricci (2004) closure of the perception and expectation gap between hospitality education and industry is considered the main key to reduce the employees' turnover. The most negative gaps are found to be technical competency concerning the knowledge and skills essential to producing the product or service. This competency needs further developments and improvements by hospitality education and hospitality industry. The hospitality industry should develop the cooperation with hospitality, educational institutions; this cooperation could endeavor to develop the internship and curriculums in which meet the hospitality requirements and expectations. Interestingly, the positive variable gap found of graduated was the attitude of hospitality graduates. This indicates that the manager's perception with a graduated attitude is higher than their expectation. The factor analysis prioritized the competencies needed by the hospitality industry into 5 groups, namely, Transferable competencies, professional competencies, generic competence, analytical skills, and conceptual skill.

\section{The implication of the study}

The implications of the findings can assist instructors to raise the standards of their education procedure and outcomes in relation to the particular skills required by the industry; especially technical competency concerning the knowledge and skills essential to producing the product or service, cultural awareness, communication skills, teamwork, strategic thinking, interpersonal skills, organized, language skills, commitment. . In addition, there is a requirement for genuine endeavors for academic-industry association in deciding the course content and approaches to expand the graduates' employment skills. The findings also recommend the absences of a solid relationship among hospitality education programs and industry professionals. These relationships may become stronger through enhancing training programs and developing new activities through the cooperation of the industry by providing summer training, seminars for the students to let them know the hospitality requirements and companies' goals and mission. In addition, hospitality institutions could seek to set up working associations 


\section{Hossny, M}

with human resource management and hospitality professionals for the purpose of the community and sharing of information that will upgrade the perception of graduate preparation upon entry to the workforce. There is a need for implementing an assessment by hospitality educators to enhance student competency development so that a close the gaps between what hospitality needs and what hospitality education providers.

\section{Limitations}

Despite many statistically significant results, the study is not free from limitations. The study is conducted in five star hotels with a quantitative approach; hence, the findings cannot be generalized to all categories of the hospitality industry such as, four, three star hotels and independent organizations. Future studies in other hotels categories are necessary for a complete understanding of hospitality expectations and perception about Employment of Graduates in the hospitality industry. Second, the method for examining career goals and expectations used simple descriptive statistics, and factor analysis, thus the study has limitations in explaining the complicated relationships among different measurement such as, correlations, and regression analysis. Future Research may aim to explore the real reasons behind existing of gaps between hospitality industry and hospitality education Originality/value - The position taken in this study recognizes the need to enhance the student's competencies and skills to meet the requirement of hospitality industry. This enhancement needs collaboration of both of hospitality educators and professionals to adapt curriculums, training, and development plan to satisfy the hospitality managers' expectations

\section{References}

Alhelalat, J. A., Ineson, E. M., and Faulk, S. (2009). Branding hotel schools in relation to their partnerships with the hospitality industry. Advances in Food, Hospitality and Tourism, 1(1).

Alhelalat, J. A. (2015). Hospitality and non-hospitality graduate skills between education and industry. Journal of Business Studies Quarterly, Volume 6, Number 4 ISSN 2152-1034

Airey, D. (1988). Cross cultural approach to teaching tourism: Teaching Tourism in to the 1990's. First International Conference for Tourism Educators, University of Surrey, U.K.

Anderson, N. (2007). The practitioner-researcher divide revisited: strategic level bridges and the roles of IWO psychologists. Journal of Occupational and Organizational Psychology, 80, 175-183. 


\section{A Gap Analysis of the Essential Competencies Expected and Perceived from Hospitality Graduates in the Industry: The Case of Egypt}

Arora, P., and Rohmetra, N. (2010). Cultural intelligence: leveraging differences to bridge the gap in the international hospitality industry. International Review of Business Research Papers, 6(5), 216-234.

Barrie, S. C. (2006). Understanding what we mean by the generic attributes of graduates. Higher Education, 51(2), 215-241.doi: 10.1007/s10734004-6384-7

Baum, T. (1995) Managing Human Resources in the European Hospitality Industry: A strategic Approach. London: Chapman and Hall

Baum, T. (2002). Skills and training for the hospitality sector: a review of issues. Journal of Vocational Education and Training, 54(3), 343-363. doi: $10.1080 / 13636820200200204$

Baum, T. 2006. Skills and training for the hospitality sector: A review of issues. Journal of Vocational Education and Training, 54:3, 343-363

Baum, T., Dutton, E., Karimi, S., Kokkranikal, J., Devine, F., and Hearns, N. (2007). Cultural diversity in hospitality work. Cross Cultural Management: An International Journal, 14(3), 229-239. doi: $10.1108 / 13527600710775775$

Belli, G. (2010). Bridging the researcher-practitioner gap: views from different fields. Paper presented at the 8th International Conference on Teaching Statistics, Ljubljana. Retrieved from http://icots.info/icots/8/cd/pdfs/invited/ICOTS8_1D3_BELLI.pdf

Bennett, R., Dunne, E., and Carre, C. (1999). Patterns of core and generic skill provision in higher education. Higher Education, 37, 71-93. doi: 10.1023/A:1003451727126

Bennett, R. (2002). Employers' demands for personal transferable skills in graduates: a content analysis of 1000 job advertisements and an associated empirical study. Journal of Vocational Education and Training, 54(4), 457-475. doi: 10.1080/13636820200200209

Beth, G. Chung-Herrera, Enz, A. Cathy and LankauMelenie J. (2003), "Grooming future hospitality leaders: A competencies model", The Cornell Hotel and Restaurant Administration, Quarterly Volume 44, Issue 3, June 2003, Pages 17-25.

Blue, G. M., and Harun, M. (2003). Hospitality language as a professional skill. English for Specific Purposes, 22(1), 73-91.doi: 10.1016/S08894906(01)00031-X

Bronwell, J. (2008). Leading on land and sea: competencies in context. International Journal of Hospitality Management, 27(2), 137-150.doi: 10.1016/j.ijhm.2007.11.003

Brownlie, D., Hewer, P., Wagner, B., and Svensson, G. (2008). Management theory and practice: bridging the gap through multidisciplinary lenses. European Business Review, 20(6), 461-470 


\section{Hossny, M}

Buergermeister, J (1983) 'Assessment of the educational skills and competencies needed by beginning hospitality managers', Hospitality Education and Research Journal, Vol 8 No 1 pp 38 - 53.

Cho, S., Erdem, M., and Johanson, M. (2007). Hospitality graduate education: A view from three different stakeholder perspectives. Journal of Hospitality \& Tourism Education 4, (18) 45-55.

Christou, E (2002) 'Revisiting Competencies for Hospitality Management: Contemporary Views of the Stakeholders', Journal of Hospitality \& Tourism Education, Vol 14 No 1 pp 25 - 32

Cichy, R Sciarini, M and Patton, M (1992) 'Food - Service Leadership: Could Attila Run a Restaurant?', The Cornell H.R.A. Quarterly, Vol 33 No 1 pp. 47-55.

Chung-Herrera, B. G., Enz, C. A. and Lankau, M. J. (2003). A competencies model: grooming future hospitality leaders. Cornell Hotel and Restaurant Administration Quarterly, 44(17), 17-25.

Crebert, G., Bates, M., Bell, B., Patrick, C. J., and Cragnolin, V. (2004). Ivory tower to concrete jungle revisited. Journal of Education and Work, 17(1), 47-70.doi: 10.1080/136390804200174192

Crisp, A. (2010, December). International perceptions of business education in Canada. Paper presented at the meeting of the Canadian Federation of Business Schools Deans, Toronto.

Dawson, M., Abbott, J., \& Shoemaker, S. (2011). The hospitality culture scale: a measure of organizational culture and personal attributes. International Journal of Hospitality Management, 30, 290-300.doi: 10.1016/j.ijhm.2010.10.002

DEETYA. (1998). Interim Report on Research on Employer Satisfaction with Graduate Skills. Canberra, Australia: Department of Employment, Education, Training and Youth Affairs, Australia

Dillman, D.A. 2007. Mail and internet Surveys: The Tailored Design Method, second ed. John Wiley \& Sons, Inc, Hoboken, New Jersey.

Fallows, S., and Steven, C. (2000). Building employability skills into the higher education curriculum: a university-wide initiative. Education and Training, 42(2), 75-82.doi: 10.1108/00400910010331620

Gill Rowley et al., 2000. Employers Skill Survey: Case study - Hospitality Sector [online] Bristol Business School, University of the West of England, Bristol UK. Available at: $<$ http://dera.ioe.ac.uk/15174/1/Employers\%20skill\%20survey\%20$\% 20$ case $\% 20$ study $\% 20-\% 20$ hospitality\%20sector.pdf $\$$ [Accessed March 12, 2018]. 


\section{A Gap Analysis of the Essential Competencies Expected and Perceived from Hospitality Graduates in the Industry: The Case of Egypt}

Goodman, R., and Sprague, L. (1991). The future of hospitality education: meeting the industry's needs. The Cornell Hotel and Restaurant Administration Quarterly, 32(2), 67-70.doi: $10.1177 / 001088049103200220$

Gow, K., and McDonald, P. (2000). Attributes required of graduates for the future workplace. Journal of Vocational Education and Training, 52(3), 373-396.doi: 10.1080/13636820000200126

Gray, B., Fam, K., and Llanes, V. (2003). Branding universities in Asian markets. Journal of Product \& Brand Management, 12(2), 108-120.

Grobler, P.A. and Diedericks, H., 2009. Talent management: An empirical study of selected South African hotel groups. Southern African Business Review 13:3, 1-27

Hair, JF, Anderson, RE, Tatham, RL and Black, WC 1998. Multivariate data analysis, 5th edn, Prentic-hall Inc, New Jersy, USA

Hansson, B (2001) 'Competency models: are self-perceptions accurate enough?, Journal of European Industrial Training, Vol 25 No 9 pp 428 441.

Harkison, T., Poulston, J., and Kim, J. G. (2011). Hospitality graduates and managers: the big divide. International Journal of Contemporary Hospitality Management, 23(3), 377-392.doi: 10.1108/09596111111122541

Harper, S., Brown, C., and Irvine, W. (2005). Qualifications: a fast track to hotel general manager? International Journal of Contemporary Hospitality Management,17(1), 51-64.doi: 10.1108/09596110510577671

Hind, D., Moss, S., and McKellan, S. (2007, October). Innovative assessment strategies for developing employability skills in the tourism and entertainment management curriculum at Leeds Metropolitan University. Paper presented at EuroCHRIE, Leeds, UK

Hochschild, A. R. (1983). The Managed heart: Commercialisation of Human Feeling. Berkely, CA: University of California Press.

Hodges, D., and Burchell, N. (2003). Business Graduate Competencies: Employers' Views on Importance and Performance. Asia-Pacific Journal of Cooperative Education, 4(2), 16-22.

Huang, Y., and Lin, C. (2011). Management trainee core competencies in the hospitality industry: differences between managers and scholars. Journal of Human Resources in Hospitality and Tourism, 10(1), 1-13.doi : $10.1080 / 15332845.2010 .500166$

Jebril A. Alhelalat (2015). Hospitality and non-hospitality graduate skills between education and industry. Journal of Business Studies Quarterly 2015, Volume 6, Number 4 ISSN 21521034 


\section{Hossny, M}

.Jenkins, C. (1999). Tourism Academics and Tourism Practitioners: Bridging the Great Divide. In Contemporary Issues in Tourism Development (pp. 52-63). London: Routledge.

Johanson, M; Ghiselli, R; Shea, L J.; and Roberts, C, (2010). "Revealing Key Competencies of

Hospitality Graduates Demanded by Industry: A 25-year review" (2010). International CHRIE Conference-Refereed Track. 5. http://scholarworks.umass.edu/refereed/CHRIE_2010/Saturday/5

Kay, C and Russette. J (2000) 'Hospitality Management Competencies', The Cornell H.R.A. Quarterly, Vol 41 No 2 pp 52-61.

Kember, D., and Leung, D. Y. P. (2005). The influence of the teaching and learning environment on the development of generic capabilities needed for a knowledge based society. Learning Environments Research, 8(3), 245-266.doi: 10.1007/s10984-005-1566-5

Lafer, G. (2004). What is 'skill'? Training for discipline in the low-wage labour market. In C. Warhurst, I. Grugulis, \& E. Keep (Eds.), The Skills That Matter (pp. 109-127). Basingstoke, UK: Palgrave Macmillan.

Lilien, G. L. (2011). Bridging the Academic-Practitioner Divide in Marketing Decision Models.Journal of Marketing, 75, 196-210.

Lolli, J. C. (2013). Interpersonal communication skills and the young hospitality leader: Are they prepared? International Journal of Hospitality Management, 32, 295-298. doi:10.1016/j.ijhm.2012.02.010

Millar, Michelle; Mao, Zhenxing; and Moreo, Patrick, "Hospitality Management Educators vs. the Industry: a Competency Assessment" (2008). Hospitality Management. Paper 6. http://repository.usfca.edu/hosp/6 Implications

Milman, A., and Ricci, P. (2004). Predicting job retention of hourly employees in the lodging industry. Journal of Hospitality and Tourism Management, 11 (1), 28-41.

Mkono, M. (2010). Cultural awareness and the global hospitality business. Tourism Analysis, 15(2), 273-278.doi: $10.3727 / 108354210 \times 12724863553686$

Moyle, D., 2008. The growing skills crisis in the tourism sector. In Human Resources Development Review 2008: Education, employment and skills in South Africa, ed. Kraak and Karen. Press, 528-554. Cape Town, South Africa: HSRC Press.

Nelson, A. A., and Dopson, L. (1999). Future of hotel education: required skills and knowledge for graduates of US hospitality programs beyond 


\section{A Gap Analysis of the Essential Competencies Expected and Perceived from Hospitality Graduates in the Industry: The Case of Egypt}

year 2000 - part one. Journal of Tourism and Hospitality Education, 13(5), 58-67.doi: 10.1080/10963758.2001.10696715

Nickson, D., Baum, T., Losekoot, E., Morrison, A., and Frochot, I. (2005). Skills, Organisational Performance and Economic Activity in the Hospitality Industry: A Literature Review. Oxford/Warwick, UK: ESRC SKOPE.

Nunnally, J. C., and Bernstein, I. H. (1994). Psychometric theory (3rd ed.). New York, NY: McGraw-Hill, Inc.

Ogbeide, G. C. (2006). Employability skills and students' self-perceived competence for careers in the hospitality industry (Doctoral dissertation).

University of Missouri-Columbia, Missouri

Raybould, M., and Wilkins, H. (2005). Over qualified and under experienced: turning graduates into hospitality managers. International Journal of Contemporary Hospitality Management, 17(3), 203-216.doi: $10.1108 / 09596110510591891$

Raybould, M., and Wilkins, H. (2006). Generic skills for hospitality management: a comparative study of management expectations and student perceptions. Journal of Hospitality and Tourism Management, 13(2), 177-188.doi: 10.1375/jhtm.13.2.177

Riegel, C. and Dallas, M. (2006). Hospitality and tourism: Careers in the world's largest industry. Guide to College Programs in Hospitality, Tourism, \& Culinary Arts. Council on Hotel, Restaurant, and Institutional Education, 5-50.

Roberts, L., and Whitelaw, P., (1999). 'Turning Waiters into Managers', paper presented to the CAUTHE National Research Conference, February, Adelaide.

Spake, D., Joseph, M., and Weldy, T. (2010). Public University Branding: What Do Students Want to Know about a Prospective Institution and How Do They Get Information?. Journal of Academic Administration in Higher Education, 6(2), 9-16.

Spowart, J. (2011). Hospitality Students' Competencies: Are They Work Ready? Journal of Human Resources in Hospitality and Tourism, 10(2), 169-181.doi: 10.1080/15332845.2011.536940

Stanton, A. D. (2006). Bridging the academic/practitioner divide in marketing: An undergraduate course in data mining. Marketing Intelligence \& Planning, 24(3), 233-244.

Tas, R LaBrecque, S and Clayton, H (1996) 'Property-Management Competencies for Management Trainees', The Cornell H.R.A. Quarterly, Vol 37 No 4 pp 90-96.

Tesone, D. V., and Ricci, P. (2005). Job competency expectations for hospitality and tourism employees: perceptions of educational preparation. Journal of Human Resources in Hospitality \& Tourism, 4(2), 53-64.doi: 10.1300/J171v04n02_03 


\section{Hossny, M}

Warhurst, C., and Nickson, D. (2007). Employee experience of aesthetic labour in retail and hospitality. Work, Employment and society, 21(1), 103-120.doi: 10.1177/0950017007073622

Waryszak, R. Z. (1999). Students' expectations from their cooperative education placements in the hospitality industry: an international perspective. Education and Training, 41(1), 33-40.

Williams, J., and DeMicco, F. (1998). The challenge of multi-departmental management for future hospitality graduates. Journal of Tourism and Hospitality Education, 10(1), 13-17.doi: 10.1080/10963758.1998.10685167

Williams, D. (2005). Hospitality management curriculum design and graduate success in the hospitality industry. The Consortium Journal of Hospitality and Tourism, 9(1), 25-34.

Yorke, M., and Harvey, L. (2005). Graduate attributes and their development. New Directions for Institutional Research, 2005(128), 41-58.doi: 10.1002/ir. 162

Zegward, K. E., and Hodges, D. (2003). Science and technology stakeholders' ranking of graduate competencies part 4: faculty perspective. Asia-Pacific Journal of Cooperative Education 4(2), 36-48.

Zeithaml, V. A., Bitner, M. J., and Gremler, D. D. (2006). Services Marketing: Integrating Customer Focus Across the Firm (4th ed.). New York, NY: McGraw-Hill/Irwin. 